\title{
In vitro antiproliferative, antioxidant, anti-inflammatory activities and phenolic profile of Centaurea saligna (K.Koch) Wagenitz
}

\author{
Aybeniz YILDIRIM ${ }^{1,2}$ (D), Ali ŞEN 1 (D) , Fatih GÖĞER 3 (D), Özlem BİNGÖL ÖZAKPINAR 4 (D), \\ Leyla BİTiş 1 * (D)
}

1 Department of Pharmacognosy, Faculty of Pharmacy, Marmara University, İstanbul, Turkey.

2 Institue of Health Sciences, Marmara University, İstanbul, Turkey.

3 Department of Pharmacognosy, Faculty of Pharmacy, Anadolu University, Eskişehir, Turkey.

4 Department of Biochemistry, Faculty of Pharmacy, Marmara University, İstanbul, Turkey.

* Corresponding Author. E-mail: leylabitis@marmara.edu.tr (L.B.); Tel. +90-532-285 5109.

Received: 14 June 2021 / Revised: 18 October 2021 / Accepted: 25 October 2021

\begin{abstract}
In this study, methanol extract (CSM) and their hexane (CSH), chloroform (CSC), ethyl acetate (CSEA) and aqueous methanol fractions (CSAM) prepared from aerial parts of Centaurea saligna (K.Koch) Wagenitz were investigated for in vitro antiproliferative, anti-inflammatory and antioxidant activity. Anticancer, antioxidant, antiinflammatory activities of these extracts were carried out by MTT, DPPH-ABTS, 5-lipoxygenase methods, respectively. Methanol extract and its fractions of C. saligna were evaluated for their cytotoxicity against MCF-7, A549, HeLa, HT-29, $\mathrm{PC}-3$ cell lines at a concentration of $50 \mu \mathrm{g} / \mathrm{ml}$. Total flavonoid and phenolic contents of extracts were detected by $\mathrm{AlCI}_{3}$ and Folin-Ciocalteu methods, respectively. Analysis of phytochemical of CSEA, showing a strong anti-inflammatory activity with good antioxidant activity, was performed by LC-MS/MS. CSC exhibited the best antiproliferative activity against HeLa, HT-29, MCF-7 cell lines with 50.18\%, 46.88\%, 45.42\% mortality, respectively. CSEA showed the highest antioxidant activity with $\mathrm{IC}_{50}$ values of $82.05 \mu \mathrm{g} / \mathrm{ml}$ and $108.4 \mu \mathrm{g} / \mathrm{ml}$ against ABTS and DPPH radicals, respectively. The highest total phenolic amounts have been determined in CSEA with value of $379.2 \mathrm{mg}$ GAE/g extract. In the same way, the highest total flavonoid amounts have been observed in CSEA with values of $170.3 \mathrm{mg}$ QE/g extract. CSEA showed strong anti-inflammatory activity with $\mathrm{IC}_{50}$ value of $0.10 \mu \mathrm{g} / \mathrm{ml}$ when compared to indomethacine as standard $(22.39 \mu \mathrm{g} / \mathrm{ml})$. Analysis of CSEA by LC-MS/MS revealed that the major compounds were quinic acid, 5-caffeoylquinic acid, apigenin C-hexoside-C-pentoside, p-coumaroylquinic acid, quercetin glucoside, di-caffeoylquinic acid, isorhamnetine glucoside, isorhamnetin glucuronide and isorhamnetin derivative. These results proved that CSEA has significant anti-inflammatory and antioxidant activity and CSC has good antiproliferatif activity. Also, the results demostrate that CSEA and CSC are a good source for further bioactivity-guided isolation in discovering new active antioxidant, anti-inflammatory and antiproliferative compounds.
\end{abstract}

KEYWORDS: Centaurea saligna; antioxidant activity; antiproliferative activity; anti-inflammatory activity.

\section{INTRODUCTION}

Mankind have used plants as a source of food and medicine since humanity existed. According to the report of the World Health Organization (WHO, 2002), more than $60 \%$ of the people on earth still uses herbs primarily in the treatment of many diseases, due to the bioactivity of the their phytochemicals (mainly secondary metabolites) [1].

Cancer, one of the major causes of death in the world, is a complex genetic disease characterized by uncontrolled cell growth, metastasis and angiogenesis [2]. Chemotherapy and radiotherapy among the applied cancer treatments lead to high costs and many side effects. All these side effects reduce the quality of life and discourage patients from adapting to treatment. This situation leads to the progression of cancer and related complications [3]. Therefore, there is a need to discover stronger anticancer drugs as well as being more selective and less toxic than those currently in use [4]. Various herbs with different pharmacological properties have been shown to be potent in cancer treatment because they contain antitumor compounds without causing toxicity [5].

How to cite this article: Yıldırım A, Şen A, Göğer F, Özakpınar ÖB, Bitiş L. In vitro antiproliferative, antioxidant, anti-inflammatory activities and phenolic profile of Centaurea saligna (K.Koch) Wagenitz. J Res Pharm. 2022; 26(1): 163-173. 
The idea that inflammation is an important factor in tumor progression is supported. Many cancers are caused by infection, chronic irritation and inflammation. It turns out that the environment created by inflammatory cells is an important mediator of the neoplastic process in the proliferation, survival and migration of tumors to other tissues. These views support new anti-inflammatory treatment approaches to cancer development [6]. It has been demonstrated that the underlying cause of many latent tumors is chronic inflammation that causes premalignant cells to become fully developed cancers [7].

The most important target of reactive oxygen species is DNA. ROS (reactive oxygen species) causes cancer by inducing various DNA damage, including rupture of DNA strands, base modification and DNA protein crosslinking [8]. Various types of 'Reactive species' (RS) are produced in the human body and many of them are powerful oxidizing agents that can damage DNA and other biomolecules. Increased RS formation may support the development of malignancy and 'RS' occurring at normal levels may be responsible for the increased risk of cancer development in the elderly [9]. Thus, antioxidants can act in preventing cancer formation by reducing these "reactive species".

Medicinal plants have been the source of pharmaceutical bioactive compounds against various types of diseases for years [10]. Many of the Centaurea species have been used in conventional medicine for the treatment of antirheumatic [11-12], antimalarial [13], gastric pain, indigestion [14], kidney disease, sedative [15], diuretic, [16] cholagogue, blood cleanser, antigout [17], internal cancers [18], headache, antipyretic [19]. Centaurea saligna, an endemic plant for Turkey, is used in the treatment of many diseases such as astringent [20], coagulation [21], antidiabetic [22], wound healing [23] among the people. In addition, there are many biological activity experiments such as antioxidant [24], antiproliferative [25], antimicrobial [26], antidiabetic [1], antialzheimer and anti-inflammatory [27] activity on Centaurea species.

Centaurea species has 192 species, 114 of which are endemic to Turkey [28] and has been the subject of many chemical studies that allow the obtaining of acetylenes, flavonoids, sesquiterpene lactones and lignans as the main characteristic secondary metabolites [29]. Also, there are many essential oil studies on Centaurea species [30].

In this study, the antiproliferative activity and anti-inflammatory activity of Centaurea saligna were reported against cancer cell lines (HeLa [cervical cancer cell line], A549 [lung cancer cell line], HT-29 [colon cancer cell line], PC-3 [prostate cancer cell line]) and 5-LOX (5-lipoxygenase) enzyme, respectively, for the first time.

\section{RESULTS}

Table 1 summarizes the cytotoxic activity of methanol extract and fractions of Centaurea saligna. According to the National Cancer Institute (NCI), it has been suggested that if the cytotoxic $\mathrm{ED}_{50}$ (Effective Dose 50) for plant extracts is $\leq 30 \mu \mathrm{g} / \mathrm{ml}$, these extracts may contain a promising rate of anticancer compounds and it would be significant to isolate the compounds from this extract [31]. In A549 cell line, the methanol extract showed moderate cytotoxic activity with cell death rate of $50.57 \%$ while CSH, CSC, CSEA and CSAM exhibited weak cytotoxic activity. In HeLa cell line, CSM showed good an antiproliferative activity with cell death rate of $59.84 \%$ at $50 \mu \mathrm{g} / \mathrm{ml}$ concentration. CSC exhibited the best activity $(50.18 \%)$ following CSM. As seen in the Table 1, CSM showed the best antiproliferative activity in HT-29 cell line with $53.65 \%$ cell death rate. The cytotoxic activity of these extracts against HT-29 was, in decreasing order, CSM > CSAM > CSC > CSEA > CSH exhibited moderate cytotoxic activity against HT-29. Methanol extract and its all fractions showed a poor antiproliferative activity against the PC-3 cell line. CSC, the most active fraction tested in the MCF-7 cell line, exhibited moderate cytotoxic activity with a cell death rate of $45.42 \%$, CSM showed the second best activity against MCF-7 while CSH, CSEA, CSAM exhibited weak activity.

Table 1. Antiproliferative activity of various extracts obtained from aerial parts of C. saligna.

\begin{tabular}{|c|c|c|c|c|c|}
\hline \multirow{2}{*}{$\begin{array}{c}\text { Ekstract and } \\
\text { fractions }\end{array}$} & A549** & HeLa $^{* *}$ & HT-29** & PC-3** & MCF-7** \\
\hline & \multicolumn{5}{|c|}{$\%$ death rate at $50 \mu \mathrm{g} / \mathrm{ml}$ concentration } \\
\hline $\mathrm{CSM}^{*}$ & 50.57 & 59.84 & 53.65 & 29.01 & 41.05 \\
\hline $\mathrm{CSH}^{*}$ & 28.17 & 41.15 & 44.24 & 23.68 & 23.97 \\
\hline $\mathrm{CSC}^{*}$ & 33.12 & 50.18 & 46.88 & 27.94 & 45.42 \\
\hline CSEA* $^{*}$ & 35.89 & 36.94 & 44.74 & 19.42 & 32.39 \\
\hline CSAM* & 32.87 & 37.79 & 49.37 & 10.55 & 27.01 \\
\hline
\end{tabular}

"Abbreviations: CSM, CSH, CSC, CSEA, CSAM show the methanol extracts and its n-hexane, chloroform, ethyl acetate, and aqueous methanol fractions of Centaurea saligna respectively. ${ }^{* *}$ A549: Lung cancer, HeLa: Cervical cancer, HT-29: Colon cancer, PC-3: Prostate cancer, MCF-7: Breast cancer 
As shown in Table 2, methanol extract of $C$. saligna and its fractions were found to possess concentrationdependent inhibitory activity against $\mathrm{DPPH}$ radical. A low $\mathrm{IC}_{50}$ value indicates the high antioxidant activity. Therefore, CSEA with $\mathrm{IC}_{50}$ value of $108.4 \mu \mathrm{g} / \mathrm{ml}$ was superior than other fractions of $C$. saligna for DPPH assay. DPPH radical scavenging activity of $C$. saligna extract and fractions decreased in the following order: CSEA > $\mathrm{CSM}>\mathrm{CSAM}>\mathrm{CSC}>\mathrm{CSH}$ (Table 2). In ABTS assay, CSEA with $\mathrm{IC}_{50}$ value of $82.05 \mu \mathrm{g} / \mathrm{ml}$ was observed more active than other fractions of $C$. saligna. ABTS radical scavenging activity of $C$. saligna extract and fractions decreased in the following order: CSEA $>$ CSC $>$ CSM $>$ CSAM $>$ CSH (Table 1). Total phenolic amount were determined according to the equation $\left(y=0.109 x+0.2464, r^{2}: 0.9888\right)$ obtained from calibration curve as gallic acid equivalent (mg/g extract), while total flavonoid amount were determined according to the equation $\left(y=0.019 x+0.0001, r^{2}: 0.9937\right)$ obtained from calibration curve as quercetin equivalent (mg/g extract). As shown in Table 3, the content of total phenolics in extract and fractions varied from 26.10 to $379.2 \mathrm{mg}$ of gallic acid equivalent per gram dried extract and the total flavonoid contents varied from 8.51 to $170.3 \mathrm{mg}$ quercetin equivalent per gram dried extract. The maximum total phenolic and flavonoid levels have been observed in CSEA which showed the highest activity in DPPH, ABTS and 5-lipoxygenase inhibitory acitivity tests. CSEA exhibited very strong anti-lipoxygenase activity with $\mathrm{IC}_{50}$ value of $0.10 \mu \mathrm{g} / \mathrm{ml}$ when compared to indomethacine as standard (indomethacine $\mathrm{IC}_{50}: 22.39 \mu \mathrm{g} / \mathrm{ml}$ ) (Table 2).

Table 2. Antioxidant and anti-inflammatory activity of various extract obtained from aerial parts of C. saligna.

\begin{tabular}{|c|c|c|c|}
\hline \multirow{3}{*}{$\begin{array}{l}\text { Extracts } * / \\
\text { Standards }\end{array}$} & \multicolumn{2}{|c|}{ Antioxidant activity } & \multirow{2}{*}{$\begin{array}{c}\text { Anti-inflammatory } \\
\text { activity }\end{array}$} \\
\hline & $\begin{array}{c}\text { DPPH radical } \\
\text { scavenging activity }\end{array}$ & $\begin{array}{l}\text { ABTS radical scavenging } \\
\text { activity }\end{array}$ & \\
\hline & \multicolumn{3}{|c|}{$\mathrm{IC}_{50}(\mu \mathrm{g} / \mathrm{mL})$} \\
\hline CSM & $125.4 \pm 0.42^{\mathrm{d}}$ & $117.2 \pm 0.14 \mathrm{~d}, \mathrm{e}$ & $7.09 \pm 0.21^{b}$ \\
\hline $\mathrm{CSH}$ & $2039 \pm 3,54^{\mathrm{f}}$ & $264.6 \pm 0.28^{f}$ & $24.99 \pm 0.01^{c}$ \\
\hline CSC & $215.0 \pm 0.14 \mathrm{e}$ & $110.0 \pm 0.85^{\mathrm{d}}$ & $23.03 \pm 0.66^{c}$ \\
\hline CSEA & $108.4 \pm 0.07 c$ & $82.05 \pm 1.49 c$ & $0.10 \pm 0.02^{\mathrm{a}}$ \\
\hline CSAM & $138.7 \pm 0.50 \mathrm{~d}$ & $124.6 \pm 0.56 \mathrm{e}$ & $19.10 \pm 1.49 \mathrm{c} \quad 1$ \\
\hline $\mathrm{AA}^{* *}$ & $17.6 \pm 0.37 a$ & $14.5 \pm 0.32^{\mathrm{a}}$ & \\
\hline Trolox** & $14.54 \pm 0.18^{a}$ & $13.00 \pm 0.21^{\mathrm{a}}$ & \\
\hline $\mathrm{BHA}^{* *}$ & $57.15 \pm 0.09 \mathrm{~b}$ & $17.06 \pm 0.58^{\mathrm{a}}$ & \\
\hline $\mathrm{BHT}^{* *}$ & $213.6 \pm 15.20 \mathrm{e}$ & $26.82 \pm 1.12^{\mathrm{b}}$ & \\
\hline INDO** & & & $22.39 \pm 0.26^{c}$ \\
\hline
\end{tabular}

*Abbreviations: CSM, CSH, CSC, CSEA, CSAM show the methanol extracts and its n-hexane, chloroform, ethyl acetate, and aqueous methanol fractions of Centaurea saligna, respectively. **AA: Ascorbic acid; BHA: Butylhydroxyanisole; BHT: Butylhydroxytoluene; INDO: Indomethacine ${ }^{* *}$ Each value in the table is represented as mean \pm SD $(n=3)$. The values with different letter superscripts in the same column indicate significant differences $(p<0.05)$.

Table 3. Total flavonoid and phenol contents of various extracts obtained from aerial parts of C. saligna.

\begin{tabular}{lcc}
\hline $\begin{array}{l}\text { Extracts* } \\
\text { Standards }\end{array}$ & $\begin{array}{c}\text { TPC } \\
(\text { mg GAE/g extract) }\end{array}$ & $\begin{array}{c}\text { TFC } \\
(\text { mg QE/g extract })^{* *}\end{array}$ \\
\hline CSM & $133.3 \pm 3.77^{\mathrm{c}}$ & $80.04 \pm 0.60^{\mathrm{c}}$ \\
CSH & $26.10 \pm 0.89^{\mathrm{a}}$ & $8.51 \pm 0.12^{\mathrm{a}}$ \\
CSC & $210.5 \pm 0.69^{\mathrm{d}}$ & $98.38 \pm 5.14^{\mathrm{d}}$ \\
CSEA & $379.2 \pm 1.69 \mathrm{e}$ & $170.3 \pm 2.31^{\mathrm{e}}$ \\
CSAM & $50.22 \pm 3.35^{\mathrm{b}}$ & $48.14 \pm 1,49^{\mathrm{b}}$
\end{tabular}

*Abbreviations: CSM, CSH, CSC, CSEA, CSAM show the methanol extracts and its n-hexane, chloroform, ethyl acetate, and aqueous methanol fractions of Centaurea saligna respectively. ${ }^{* *}$ Total phenolic and total flavonoid contents were expressed as gallic acid equivalent (GAE) and quercetin equivalent (QE), respectively. ${ }^{* * *}$ Each value in the table is represented as mean $\pm S D(n=3)$. The values with different letter superscripts in the same column indicate significant differences $(\mathrm{p}<0.05)$. 
In this study, chemical compounds ethyl acetate fraction of $C$. saligna due to its more prominent antioxidant and antiinflammatory activities compared to those of the other fractions were investigated by using LC-MS/MS. Nine phenolic compounds including quinic acid, 5-caffeoylquinic acid, apigenin Chexoside-C-pentoside, p-coumaroylquinic acid, quercetin glucoside, di-caffeoylquinic acid, isorhamnetine glucoside, isorhamnetin glucuronide and isorhamnetin derivative were detected by LC/MS-MS (Figure 1) (Table 4).

Table 4. Phenolic contents of ethyl acetate fractions of C. saligna.

\begin{tabular}{rcccc}
\hline Rt & {$[\mathbf{M}-\mathbf{H}] \mathbf{m} / \mathbf{z}$} & Fragments & Identification & Ref \\
\hline 3.8 & 191 & 173,127 & Quinic acid & {$[65]$} \\
6.8 & 353 & $191,173,127$ & 5-caffeoylquinic acid & {$[65]$} \\
7.3 & 563 & $343,387,353$ & Apigenin C-hexoside-C-pentoside & {$[66]$} \\
8.5 & 337 & $191,163,145$ & p-coumaroylquinic acid & {$[66]$} \\
9.7 & 463 & 301 & Quercetin glucoside & {$[66]$} \\
11.5 & 515 & $353,191,173$ & Di-caffeoylquinic acid & {$[66]$} \\
11.9 & 477 & 315,299 & Similar to Isorhamnetin glucoside & {$[66]$} \\
13.3 & 491 & 329,313 & Unknown similar to Isorhamnetin & {$[66]$} \\
17.6 & 435 & $315,301,297,151$ & Similar to İsorhamnetin derivative (EA) & {$[66]$} \\
\hline
\end{tabular}

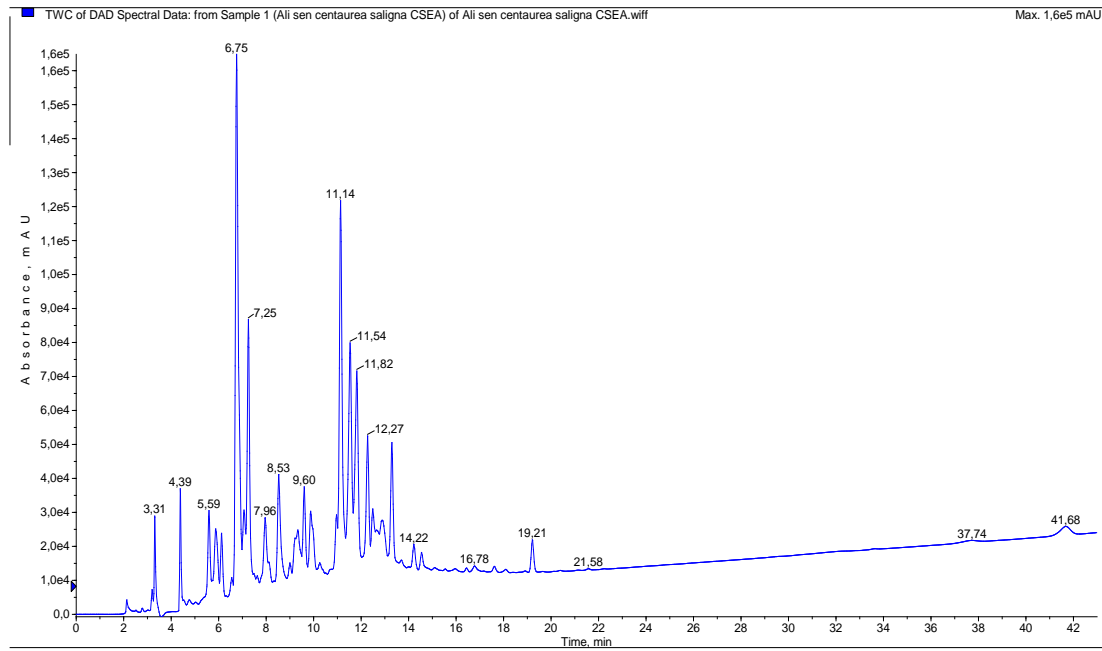

Figure 1. LC-MS/MS chromatogram of ethyl acetate fraction of C. saligna.

\section{DISCUSSION}

The study was aimed to research the phenolic compounds of active CSEA as well as the antioxidant, anti-inflammatory and anticancer potential of Centaurea saligna extracts. There are many articles in the literature on the antioxidant effects of the different extracts and compounds from many Centaurea species. The $\mathrm{DPPH}$ test is often used to understand the antioxidant capability of plant extracts containing polar components. DPPH, is a purple radical, when it reacts with an antioxidant, it turns into yellow (diphenyl picrylhydrazine). DPPH radical scavenging efficiency of the extracts was evaluated by using $\mathrm{IC}_{50}$ values. A low $\mathrm{IC}_{50}$ value proves that the sample has strong antioxidant activity.

Some researchers stated that DPPH assay was associated with high phenolic content [32]. It is generally approved that the ABTS test gives more significant results than the DPPH test when samples including lipophilic, hydrophilic and highly pigmented antioxidant compounds are analyzed [33].

Zengin et al. (2018) determined that $C$. saligna water, methanol and ethyl acetate extracts were highly possesed DPPH and ABTS radicals scavenging activity. They proved that Trolox equivalent of water, ethyl acetate, methanol and extracts of this plant $68.43,22.74,67.39 \mathrm{mg}$ TE/g extract, respectively [34]. Keser et al observed that water, ethanol, methanol and acetone extracts of C. saligna scavenged $56.48 \%, 47.58 \%, 71.96 \%$ and $21.09 \%$ of DPPH radical at $500 \mu \mathrm{g} / \mathrm{ml}$ concentration, respectively. Our activity results were higher than this study results [35]. Several studies have been conducted on the DPPH scavenging activity of different species of the Centaurea genus, such as methanol extract of $C$. kurdica $\left(\mathrm{IC}_{50}: 367.71 \mu \mathrm{g} / \mathrm{ml}\right)$, C. cheirolopha (IC $\mathrm{I}_{50}$ : 
$227.45 \mu \mathrm{g} / \mathrm{ml})$, C. amanicola $\left(\mathrm{IC}_{50}: 581.36 \mu \mathrm{g} / \mathrm{ml}\right)$, C. rigida $\left(\mathrm{IC}_{50}: 475.06 \mu \mathrm{g} / \mathrm{ml}\right)$, C. ptosimopappoides $\left(\mathrm{IC}_{50}: 745.13\right.$ $\mu \mathrm{g} / \mathrm{ml}$ ) [36]. C. saligna was found to be more active than these plants. In a study in which all extracts of $C$. cyanus showed significant activity, Anwari et al. found that ethanol extract of C. cyanus leaves and flowers had 40 and $60 \mu \mathrm{g} / \mathrm{ml}$ of $\mathrm{IC}_{50}$ value against the DPPH radical, respectively [37]. According to this study, it is seen that $C$. cyanus is more active than C. saligna.

Keser et al. found that water, ethanol, methanol and acetone extracts of $C$. saligna scavenge $94.81 \%, 50.43$ $\%, 99.94 \%$ and $60.04 \%$ of ABTS radical at $500 \mu \mathrm{g} / \mathrm{mL}$ concentration, respectively [35]. In a study of ABTS radical scavenging activity conducted by Zengin et al., water, ethyl acetate, methanol extracts of $C$. saligna included 157.8, 48.87, $112.98 \mathrm{mg}$ TE/g extract, respectively [34] . Petroleum ether, acetone, methanol, and water extracts of the three Centaurea species (C. balsamita, C. depressa and C. lycopifolia) were evaluated for ABTS cation radical scavenging activity. $\mathrm{IC}_{50}$ value of the methanol extract of $C$. balsamita, $C$. depressa and C. lycopifolia were found 24.21, 70.08, and $89.05 \mu \mathrm{g} / \mathrm{ml}$ respectively. Centaurea extracts showed very poor activity that confirm the ABTS assay results of Centaurea species reported by Boğa et al [38].

Zengin et al. (2018) reported that total phenol contents of $C$. saligna water, ethyl acetate and methanol extracts were $30.18,26.21$ and $23.03 \mathrm{mg} \mathrm{GAE} / \mathrm{g}$, respectively. In the same study, it was reported that total flavonoid contents of these extracts were 25.81, 43.16 and $6.33 \mathrm{mg} \mathrm{RE} / \mathrm{g}$, respectively [34]. According to work of Keser et al., total phenolic contents of $C$. saligna water, ethanol, methanol and acetone extracts were found ranged between 35.02 and $106.27 \mu \mathrm{g}$ GAE/g while total flavonoid contents of $C$. saligna water, ethanol, methanol and acetone extracts ranged between 395.87 and $1561.25 \mu \mathrm{g} \mathrm{CE} / \mathrm{g}$ [35]. Total phenolic amount of Centaurea calcitrapa subsp. calcitrapa, C. spicata and C. ptosimopappa were found ranged between 17.25 and $120.50 \mathrm{mg} \mathrm{GAE} / \mathrm{g}$ [39]. The phenol and flavonoid content of $C$. depressa were determined as $44.5 \mathrm{mg} \mathrm{GAE} / \mathrm{g}$, $42.25 \mathrm{mg} \mathrm{QE} / \mathrm{g}$, respectively [40]. Ozsoy et al. found that the total phenol content of Centaurea antiochia var. praealta was $3.68 \mathrm{mg}$ GAE/g [27]. Total phenolic amount of methanol extract of C. aksoyi was revealed as 3.28 $\mathrm{mg} \mathrm{GAE} / \mathrm{g}$ extract while C. amaena was found as $3.62 \mathrm{mg}$ GAE/g extract. Total flavovoid content of methanol extract of C. aksoyi and C. amaena were found as 6.96 and $5.83 \mathrm{mg} \mathrm{QE} / \mathrm{g}$ extract by Albayrak et al [41]. Our results were higher when compared with these literature data.

Chloroform extract of Centaurea stenolepis Kerner, C. kilaea Boiss., C. salicifolia, C. cuneifolia were tested against 5-lipoxygenase enzyme by Şekerler et al. C. kilaea and Centaurea salicifolia showed strong antilipoxygenase activity with $\mathrm{IC}_{50}$ values of 110.0 and $97.04 \mu \mathrm{g} / \mathrm{ml}$, respectively [42]. In our current study, CSEA exhibited much stronger anti-inflammatory activity than those species.

In general, the most common study methods in the search for new anticancer agents are the screening tests against a panel of cancer cell lines. In current study, MTT assay which is based on the capability of metabolically active cells to convert the pale yellow MTT dye into a spectrophotometrically measurable blue formazan product was used.

Our findings are in line with the literature on importance of Centaurea species as cytotoxic agents against cancer cell lines. Keser et al. showed that $C$. saligna methanol extract had strong antiproliferative activity. $C$. saligna water, ethanol, methanol, acetone extracts possesed 26.13, 4.90, 28.13, $8.91 \mu \mathrm{g} / \mathrm{ml}$ values of $\mathrm{IC}_{50}$ gainst MCF-7 cell line, respectively [34]. Antiproliferative activities of $C$. baseri methanol extract were found as $\mathrm{IC}_{50}$ values of 73.3 and $45.3 \mu \mathrm{g} / \mathrm{ml}$ against A549 and MCF7 cell lines, respectively [43]. Kayacan et al., reported that $\mathrm{IC}_{50}$ values of C. nerimaniae methanol extract was $1.42 \mathrm{mg} / \mathrm{ml}$ at $48 \mathrm{~h}$ for HeLa cells [44]. In a study of Ostad et al., according to the $\mathrm{IC}_{50}$ values obtained by in vitro MTT cytotoxicity assay, among the all cell line, $C$. bruguierana ssp. belangeran total methanol extract and fractions exhibited the lowest cytotoxic activity on the HT-29 cell line. $\mathrm{IC}_{50}$ value of total methanol extract and its ethyl acetate and n-butanol fractions were found > $1000 \mu \mathrm{g} / \mathrm{ml}$. It was found that chlorofom fraction had value of $327 \mu \mathrm{g} / \mathrm{ml} \mathrm{IC}$ 50 $_{0}$ on HT-29 cell line [45]. The antitumor effects of seven different extracts of C. babylonica on A549, PC-3, MCF-7 and HeLa cells were investigated by MTT assay. Except for the water extract, all six C. babylonica extracts showed cytotoxic activity between $72 \%$ and $90 \%$ against all tested cancer cell lines. It was found that acetone extract with $\mathrm{IC}_{50}$ values in the range of 3-6 $\mu \mathrm{g} / \mathrm{ml}$ against MCF-7, HeLa and PC-3 cell lines showed good antiproliferative effects. [46].

In the current study, the phytochemical content of CSEA, which had strong anti-inflammatory activity and good antioxidant activity, was investigated by LC-MS/MS and it was observed that it contained phenolic compounds. These phenolic compounds have been reported to have significant anti-inflammatory activities in literature.

Many authors reported the quinic acid, 5-caffeoylquinic acid, apigenin, quercetin, isorhamnetin to be associated with many activities such as antioxidant, antiinflammatory and antiproliferative activities. In one study, it was observed that quinic acid esters contained in hot water extracts of Uncaria tomentosa (a.k.a. cat's 
claw) showed anti-inflammatory activity through mechanisms that include inhibition of the pro-inflammatory transcription factor kappa B (nuclear factor) (NF-kB) [47]. Janga et al. proved that quinic acid (QA) has been shown to have anti-neuroinflammatory, radioprotection and antioxidant activities. Pre-incubation of MOVAS (the mouse vascular smooth muscle cell line) cells with Quinic acid $(0.1,1$ and $10 \mu \mathrm{g} / \mathrm{ml})$ for 2 hours dosedependently inhibited protein expression of VCAM-1, TNF- $\alpha$-induced mRNA and monocyte adhesion. Quinic acid inhibited TNF- $\alpha$-induced phosphorylation and NK-KB activation of the MAP kinase [48]. In another experiment conducted by Lee et al., quinic acid and derivatives were tested for their inhibitory activity on nitric oxide (NO) production in an activated murine microglial cell line. The compounds significantly inhibited NO production in lipopolysaccharide (LPS) activated BV-2 cells without high cell toxicity in a microglia cell line [49].

In a study conducted, Artemisia scoparia and its new active compound 3,5-dicaffeoyl-epi-quinic acid were reported to significantly lower TSLP, TNF- $\alpha$, IL-1 $\beta$ and IL- 6 production levels by reducing caspase-1 activity [50]. Montaal et al. isolated 3,4-O-dicaffeoylquinic acid, 3,5-O-dicaffeoylquinic acid, 4,5-Odicaffeoylquinic acid and 3,4,5-O-tricaffeoylquinic acid from Solidago virgaurea. One of these compounds, 3,4,5$O$-tricaffeoylquinic acid $(50 \mathrm{mg} / \mathrm{kg}$ ) showed significant activity in inhibiting edema volume after 3 hours ( $88 \%$ of the activity of indomethacine at $10 \mathrm{mg} / \mathrm{kg}$ ). Also, Solidago virgaurea extract and isolated compounds greatly inhibited the overproduction of the inflammatory mediators TNF- $\alpha$ and IL-1p [51].

In a study tested for 5-caffeoylquinic acid, overexpression of IL-8 and mRNA induced by $\mathrm{H}_{2} \mathrm{O}_{2}$ was significantly inhibited in a dose-dependent manner in the range of $0.25-2.00 \mathrm{mmol} / \mathrm{l}$, after cells were pretreated and simultaneously treated with 5-caffeoylquinic acid. Both 5-caffeoylquinic acid (5-CQA) and caffeic acid (CA) also suppressed TNF-a-induced IL-8 secretion. At $2.00 \mathrm{mmol} / \mathrm{l}$, caffeic acid absolutely blocked the $\mathrm{H}_{2} \mathrm{O}_{2}$ - or TNF- $\mathrm{a}$-induced overexpression of IL-8 in Caco-2 cells [52]. In an another experiment for the anti-inflammatory activity of 5-caffeoylquinic acid, Coffea arabica methanol extract and 5-caffeoylquinic acid $(0.1,0.5$ and $1.0 \mathrm{mg} /$ ear) were found to reduce the volume and weight of edema caused by croton oil and phenol. Treatment with Coffea arabica methanol extract or 5-caffeoylquinic acid reduced the activity of myeloperoxidase and $\mathrm{N}$-acetyl- $\beta$-d-glucosaminides and inflammatory parameters [53].

Current epidemiological and preclinical studies provide substantial evidence in favor of the development of apigenin as a natural alternative therapy against chronic inflammatory conditions [54]. Ali et al. demonstrated that apigenin had multiple inflammatory targets. Based on in vivo, in vitro, and clinical trial studies, it has been suggested that apigenin is an effective therapeutic agent for dealing with diseases such as autoimmune disorders, rheumatoid arthritis, Alzheimer's disease, Parkinson's disease and various types of cancer [55]. A study conducted by Chiang showed that the anti-hepatoma activity of apigenin is as potent as 5-FU and its apoptotic mechanism can be mediated through the p53-dependent pathway and induction of p21 expression [56].

In one study, it was observed that quercetin exerts cytoprotective effect in normal cell cultures while inducing growth inhibition and cell death in the U138MG human glioma cell line [57]. In an experiment conducted to demonstrate the anti-inflammatory activity of quercetin, it was observed that quercetin reduced the expression of cardiovascular risk factors (SAA, fibrinogen) and human CRP in mice in vivo. It is thought that local anti-inflammatory and anti-proliferative effects in the aorta may contribute to the reduction of atherosclerosis [58]. Thus, these phenolic compounds (phenolic acids and flavonoids), along with other compounds, may be responsible for the activity of CSEA, which showed a particularly potent antiinflammatory activity.

\section{CONCLUSION}

CSC can be an important source for obtaining compounds with antiproliferative effect, while CSEA can be a source of new bioactive compounds with antioxidant and anti-inflammatory properties. However, first of all, bioactivity-guided isolation studies are needed for the isolation of active compounds from these extracts.

\section{MATERIALS AND METHODS}

\subsection{Plant material}

Aerial parts of plant were collected at their flowering period from the Patnos district of Ağr1, Turkey in August 2018 and kept in a dark and cool place until extraction. Plant was identified by Dr. Ahmet Doğan, a 
botanist of the Faculty of Pharmacy, University of Marmara. Voucher specimens were deposited in the Herbarium of the Faculty of Pharmacy, Marmara University (MARE No: 21857).

\subsection{Extraction}

About $15 \mathrm{~g}$ of dried aerial parts of Centaurea saligna were extracted with $8 \times 200 \mathrm{ml} \mathrm{MeOH}$, using an ultrasonic bath. After filtration and evaporation, the methanol extract (CSM) was dissolved in $30 \mathrm{ml} 60 \%$ aqueous methanol, and subjected to solvent-solvent partition between $\mathrm{n}$-hexane $(5 \times 50 \mathrm{ml})$, chloroform $(3 \times 50$ $\mathrm{ml})$, and ethyl acetate fractions $(2 \times 50 \mathrm{ml})$. The n-hexane, chloroform, ethyl acetate and aqueous methanol fractions of Centaurea saligna acquired by this method were coded as CSH, CSC, CSEA and CSAM, respectively. All extracts were stored at $4{ }^{\circ} \mathrm{C}$ for further analysis.

\subsection{DPPH radical scavenging activity}

DPPH radical scavenging capacity of each extract was applied by the method of Zou et al [59].

\subsection{ABTS radical-scavenging activity}

ABTS radical cation scavenging activity assay was determined according to the method described by Zou et al. [59].

\subsection{In vitro anti-lipoxygenase activity}

The anti-lipoxygenase activity was evaluated with minor modifications according to the method described by Phosrithong et al. and Yıldırım et al. [60, 61].

\subsection{Determination of total phenolic contents (TPC)}

Total phenolic amount of Centaurea saligna extracts were measured using Folin-Ciocalteau reagent and determined according to method of Gao et al. and Yildırım et al. [61, 62].

\subsection{Determination of total flavonoid contents (TFC)}

Total flavonoid content was applied following a method by Zhang at al. and Yıldırım et al. [61,63].

\subsection{Cell growth inhibition analysis}

\subsubsection{MTT Experiment}

Antiproliferative effects of the extracts were tested against in vitro five different human cancer cell lines (Hela, MCF-7, PC-3, A549 and HT-29) by MTT ([3- (4,5-dimethylthiazol-2-yl) -2,5-diphenyltetrazolium bromide]) assay. Briefly, a limited number of human cancer cells (5000/well) were seeded on a 96-well microplate. The cells were kept overnight to adhere to the base. On the second day, the medium was removed and $200 \mu \mathrm{l}$ of new medium containing test substances $(50 \mu \mathrm{g} / \mathrm{mL})$ was added. After a 72 hour incubation period, viable cells were tested by adding $200 \mu \mathrm{l}$ of $5 \mathrm{mg} / \mathrm{ml}$ MTT solution. During the 4 hour period, MTT transforms into purple colored formazan crystals in the presence of mitochondrial reductase enzyme.

The medium was removed and precipitated crystals were dissolved by shaking with $100 \mu \mathrm{l}$ of DMSO for one hour. Finally, the absorbance of the reduced MTT solution was read at $545 \mathrm{~nm}$ in a microplate reader along with control cells not applied to extract [64]. The percentage growth inhibition was calculated using following equation 1 ;

$$
\% \text { cell inhibition }=100-\{(\text { At-Ab) } /(\mathrm{Ac}-\mathrm{Ab})\} \times 100 \quad \text { Eq. } 1
$$

Where,

At $=$ Absorbance value of extract

$\mathrm{Ab}=$ Absorbance value of blank

$\mathrm{Ac}=\mathrm{Absorbance}$ value of control

\subsection{Profile of bioactive compounds}

LC-MS/MS analysis was performed using an Absciex 3200 Q trap MS/MS dedector. Experiments were conducted with a Shimadzu 20A HPLC system connected to an Applied Biosystems 3200 Q-Trap LC- 
MS/MS instrument equipped with an ESI source operating in negative ion mode. A GL Science Inertsil ODS $-3250 \times 4.6 \mathrm{~mm}, 5 \mu \mathrm{m}$ particle size, analytical column performing at $40^{\circ} \mathrm{C}$ has been used for chromatographic isolation. The solvent flow rate was kept constant at $0.5 \mathrm{ml} / \mathrm{min}$. PDA detector was used for detection. The mobile phase for the elution gradient was prepared as (A) acetonitrile: water: formic acid (10:89:1, v/v/v) and (B) acetonitrile: water: formic acid (89:10:1, v/v/v). The composition of B was increased from $10 \%$ to $100 \%$ in $40 \mathrm{~min}$. Analyst 1.6 software collected and processed the LC-ESI-MS/MS data.

\subsection{Statistical analysis}

Data are presented by calculating mean \pm standard deviations and analyzed using one-way analysis of variance (ANOVA) followed by Tukey's multiple comparison tests in GraphPad Prism 5. The differences between the means were considered significant at the $\mathrm{p}<0.05$ level.

Acknowledgements: The authors thank RPh Ibrahim Bilir for help in collecting plant material and they thank Asst. Prof. Ahmet Doğan for help in identification of the plant materials. This study is a part of PhD thesis of Aybeniz YILDIRIM entitled "Centaurea saligna (K.Koch) Wagenitz Bitkisi ile ilgili Antiproliferatif Aktivite Yönlendirmeli İzolasyon Çalışmaları". The authors also thank the Scientific and Technological Research Council of Turkey (TUBITTAK) for the financial support for this study (Project No. 319S079).

Author contributions: Concept - A.Y., A.S., L.B.; Design - A.Y., A.S., L.B.; Supervision - A.Y., A.S., L.B.; Resources A.Y., A.S., L.B.; Materials - A.Y.; Data Collection and/or Processing - A.Y., A.S., L.B.; Analysis and/or Interpretation A.Y., A.S., F.G., Ö.B.Ö., L.B.; Literature Search - A.Y., A.S., F.G., L.B.; Writing - A.Y., A.S., L.B.; Critical Reviews - A.Y., A.S., F.G., Ö.B.Ö., L.B.

Conflict of interest statement: The authors declared no conflict of interest.

\section{REFERENCES}

[1] Acet T. Determining the phenolic components by using HPLC and biological activity of Centaurea triumfetti. Plant Biosyst. 2021; 155(1): 159-164. [CrossRef]

[2] Moura LG, Tognon R, Nunes N S, Cataldi Rodrigues L, Ferreira AF, Kashima S, Covas D T, Santana M, Souto E X, Perobelli L, Simões BP, Dias-Baruffi M, Castro FA. Different expression patterns of LGALS1 and LGALS3 in polycythemia vera, essential thrombocythemia and primary myelofibrosis. J Clin Psychiatry. 2016; 69(10): 926-929. [CrossRef]

[3] Mans DR, da Rocha AB, Schwartsmann G. Anticancer drug discovery and development in Brazil: targeted plant collection as a rational strategy to acquire candidate anticancer compounds. Oncologist. 2000; 5(3): 185-198. [CrossRef]

[4] Gordaliza M. Natural products as leads to anticancer drugs. Clin Transl Oncol. 2007; 9(12): 767-776. [CrossRef]

[5] Singh A, Mehta S, Baweja L, Ahirwal and P. Mehta. Anticancer activity of Andrographis paniculata and Silybum marianum on five human cancer cell lines. J Pharmacol Toxicol. 2013; 8(1): 42-48. [CrossRef]

[6] Coussens LM, Werb Z. Inflammation and cancer. Nature. 2002; 420: 860-867. [CrossRef]

[7] Mantovani A. Inflammation by remote control. Nature. 2005; 435(7043): 752-753. [CrossRef]

[8] Toyokuni S, Okamoto K, Yodoi J, Hiai H. Persistent oxidative stress in cancer. FEBS Lett. 1995; 358(1): 1-3. [CrossRef]

[9] Halliwell B. Oxidative stress and cancer: have we moved forward? Biochem J. 2007; 401(1): 1-11. [CrossRef]

[10] Abdoua R, Shabana S, Ratebd ME. Terezine E, bioactive prenylated tryptophan analogue from an endophyte of Centaurea stoebe. Nat Prod Res. 2018; 34(4): 503-510. [CrossRef]

[11] Fernandez I, Pedro JR, Polo E. Sesquiterpene lactones from Centaurea alba and C. conifera. Phytochemistry. 1995; 38(3): 655-657 [CrossRef]

[12] Tackholm V, Student's Flora of Egypt, second ed., Cairo University Press, Cairo, Egypt 1974.

[13] Maxia A, Lancioni MC, Balia AN, Alborghetti R, Pieroni A, Loi MC. Medical ethnobotany of the Tabarkins, a Northern Italian (Ligurian) minority in South-western Sardinia. Genet Resour Crop Evol. 2008; 55: 911-924. [CrossRef] 
[14] Ghasemi Pirbalouti A, Momeni M, Bahmani, M. Ethnobotanical study of medicinal plants used by Kurd tribe in Dehloran and Abdanan districts, Ilam province, Iran. Afr J Tradit Complement Altern Med. 2013; 10(2): 368-385. [CrossRef]

[15] Akgul A, Akgul A, Senol SG, Yildirim H, Secmen O, Dogan Y. An ethnobotanical study in Midyat (Turkey), a city on the silk road where cultures meet. J Ethnobiol Ethnomed. 2018; 14: 12. [CrossRef]

[16] Rivera D, Obon C, Inocencio C, Heinrich M, Verde A, Fajardo J, Llorach R. The ethnobotanical study of local mediterranean food plants as medicinal resources in Southern Spain. J Physiol Pharmacol. 2005; 56(1): 97-114.

[17] Amiri MS, Joharchi MR. Ethnobotanical investigation of traditional medicinal plants commercialized in the markets of Mashhad, Iran. Avicenna J Phytomed. 2013; 3(3): 254-271. [CrossRef]

[18] Van Wyk BE, Gorelik B. The history and ethnobotany of Cape herbal teas. S Afr J Bot. 2017; 110: 18-38. [CrossRef]

[19] Safa O, Soltanipoor MA, Rastegar S, Kazemi M, Dehkordi KN, Ghannadi A. An ethnobotanical survey on hormozgan province, Iran. Avicenna J Phytomed. 2013; 3(1): 64-81. [CrossRef]

[20] Altundag E, Ozturk M. Ethnomedicinal studies on the plant resources of east Anatolia, Turkey. Procedia Soc Behav Sci. 2011; 19: 756-777. [CrossRef]

[21] Khatun S, Parlak KU, Polat R, Cakilcioglu U. The endemic and rare plants of Maden (Elazig) and theiruses in traditional medicine. J Herb Med. 2012; 2: 68-75. [CrossRef]

[22] Dalar A. Plant taxa used in the treatment of diabetes in Van province, Turkey. Int J Second Metab. 2018; 5(3): 171-185. [CrossRef]

[23] Dalar A, Mukemre M, Unal M, Ozgokce F. Traditional medicinal plants of Ağrı province, Turkey. J Ethnopharmacol. 2018; 226(15): 56-72. [CrossRef]

[24] Zengin G, Aktumsek A, Guler GO, Cakmak YS, Yildiztugay E. Antioxidant properties of methanolic extract and fatty acid composition of Centaurea urvillei DC. subsp. hayekiana Wagenitz. Rec Nat Prod. 2011; 5(2): 123-132. [CrossRef]

[25] Sen A, Turan SO, Bitis L. Bioactivity-guided isolation of anti-proliferative compounds from endemic Centaurea kilaea. Pharm Biol. 2017; 55(1): 541-546. [CrossRef]

[26] Güven K, Çelik S, Uysal İ. Antimicrobial activity of Centaurea species. Pharm Biol. 2005; 43(1): 67-71. [CrossRef]

[27] Ozsoy N, Kultur S, Yilmaz-Ozden T, Celik BO, Can A, Melikoglu G. Antioxidant, anti-Inflammatory, acetylcholinesterase inhibitory and antimicrobial activities of Turkish endemic Centaurea antiochia var. praealta. J Food Biochem. 2015; 39(6): 771-776. [CrossRef]

[28] Altintas A, Kose YB, Kandemir A, Demirci B, Baser KHC. Composition of the essential oil of Centaurea saligna. Chem Nat Compd. 2009; 45(2): 276-277. [CrossRef]

[29] Hegnauer R. Chemotaxonomie der Pflanzen VIII. Birkha“user- Verlag, Basel Boston, Berlin, 1989.

[30] Sen A, Kurkcuoglu M, Yildirim A, Senkardes I, Bitis L, Baser KHC. Chemical composition, antiradical, and enzyme inhibitory potential of essential oil obtained from aerial part of Centaurea pterocaula Trautv. J Essent Oil Res. 2020; 33(1): 44-52. [CrossRef]

[31] Suffness M, Pezzuto JM. Assays related to cancer drug discovery. In: Hostettmann, K. (Ed.). Methods in Plant Biochemistry: Assays for Bioactivity. Academic Press, London, 1990, pp. 71-133.

[32] Piluzza G, Bullitta S. Correlations between phenolic content and antioxidant properties in twenty-four plant species of traditional ethnoveterinary use in the Mediterranean area. Pharm Biol. 2011; 49(3): 240-247. [CrossRef]

[33] Floegel A, Kim DO, Chung SJ, Koo SI, Chun OK. Comparison of ABTS/DPPH assays to measure antioxidant capacity in popular antioxidant-rich US foods. J Food Compost Anal. 2011; 24(7): 1043-1048. [CrossRef]

[34] Zengin G, Bulut G, Mollica A, Picot-Allaind CMN, Mahomoodally MF. In vitro and in silico evaluation of Centaurea saligna (K.Koch) Wagenitz - An endemic folk medicinal plant. Comput Biol Chem. 2018; 73: 120-126. [CrossRef]

[35] Keser S, Keser F, Turkoglu I, Kaygilı Ö, Tekın S, Demir E, Karatepe M, Yılmaz O, Kırbag S, Sandal S, Turkoglu S. In vitro biological evaluation and phytochemical contents of three Centaurea L. species growing from Eastern Anatolia in Turkey. KSU J Agric Nat. 2020; 23(1): 148-156. [CrossRef]

[36] Aktumsek A, Zengin G, Guler GO, Cakmak YS, Duran A. Screening for in vitro antioxidant properties and fatty acid profiles of five Centaurea L. species from Turkey flora. Food Chem Toxicol. 2011; 49(11): 2914-2920. [CrossRef]

[37] Anvari D, Jamei R. Evaluation of antioxidant capacity and phenolic content in ethanolic extracts of leaves and flowers of some Asteraceae species. Recent Pat food, Nutr Agric. 2018; 9(1): 42-49. [CrossRef] 
[38] Boğa M, Alkan H, Ertaş A, Oral EV, Yılmaz MA, Yeşil Y, Gören AC, Temel H, Kolak U. Phytochemical profile and some biological activities of three Centaurea species from Turkey. Trop J Pharm Res. 2016; 15(9): 1865-1875. [CrossRef]

[39] Erol-Dayi Ö, Pekmez M, Bona M, Aras-Perk A, Arda N. Total Phenolic contents, antioxidant activities and cytotoxicity of three Centaurea species: C. calcitrapa subsp. calcitrapa, C. ptosimopappa and C. spicata. Free Radic Antioxid. 2011; 1(2): 31-36. [CrossRef]

[40] Hosseinimehr SJ, Pourmorad F, Shahabimajd N, Shahrbandy K, Hosseinzadeh R. In vitro antioxidant activity of Polygonium hyrcanicum, Centaurea depressa, Sambucus ebulus, Mentha spicata and Phytolacca americana. Pak J Biol Sci. 2007; 10(4): 637-640. [CrossRef]

[41] Albayrak S, Atasagun B, Aksoy A. Comparison of phenolic components and biological activities of two Centaurea sp. obtained by three extraction techniques. Asian Pac J Trop Med. 2017; 10(6): 599-606. [CrossRef]

[42] Sekerler T, Sen A, Bitis L, Sener A. Anticancer, antioxidant and anti-Inflammatory activities of chloroform extracts from some Centaurea species. Proceedings. 2018; 2(25), 1542. [CrossRef]

[43] Kose YB, Iscan G, Goger F, Akalın G, Demirci B, Baser KHC. Chemical composition and biological activity of Centaurea baseri: New species from Turkey. Chem Biodivers. 2016; 13(10): 1369-1379. [CrossRef]

[44] Kayacan S, Sener LT, Melikoglu G, Kultur S, Albeniz I, Ozturk M. Induction of apoptosis by Centaurea nerimaniae extract in HeLa and MDA-MB-231 cells by a caspase-3 pathway. Biotech Histochem. 2018; 93(5): 311-319. [CrossRef]

[45] Ostad SN, Rajabi A, Khademi R, Farjadmand F, Eftekhari M, Hadjiakhoondi A, Khanavi M. Cytotoxic potential of Centaurea bruguierana ssp. belangerana: The MTT assay. Acta Med Iran. 2016; 54(9): 583-589.

[46] Güvensen NC, Keskin D, Güneş H, Oktay MK, Yıldırım H. Antimicrobial property and antiproliferative activity of Centaurea babylonica (L.) L. on human carcinomas and cervical cancer cell lines. Ann Agric Environ Med. 2019; 26(2): 290-297. [CrossRef]

[47] Zeng K, Thompson KE, Yates CR, Miller DD. Synthesis and biological evaluation of quinic acid derivatives as antiinflammatory agents. Bioorganic Med Chem Lett. 2009; 19(18): 5458-5460. [CrossRef]

[48] Jang SA, Park DW, Kwon JE, Song HS, Park B, Jeon H, Sohn EH, Koo HJ, Kang SC. Quinic acid inhibits vascular inflammation in TNF-a-stimulated vascular smooth muscle cells. Biomed Pharmacother. 2017; 96: 563-571. [CrossRef]

[49] Lee SY, Moon E, Kim SY, Lee KR. Quinic acid derivatives from Pimpinella brachycarpa exert anti-neuroinflammatory activity in lipopolysaccharide-induced microglia. Bioorganic Med Chem Lett. 2013; 23(7): 2140-2144. [CrossRef]

[50] Nam SY, Han NR, Rah SY, Seo Y, Kim HM, Jeong HJ. Anti-inflammatory effects of Artemisia scoparia and its active constituent, 3,5-dicaffeoyl-epi-quinic acid against activated mast cells. Immunopharmacol Immunotoxicol. 2018; 40(1): 52-58. [CrossRef]

[51] Motaal AA, Ezzat SM, Tadros MG, El-Askary HI. In vivo anti-inflammatory activity of caffeoylquinic acid derivatives from Solidago virgaurea in rats. Pharm Biol. 2016; 54(12): 2864-2870. [CrossRef]

[52] Zhao Z, Shin HS, Satsu H, Totsuka M, Shimizu M. 5-Caffeoylquinic acid and caffeic acid down-regulate the oxidative stress- and TNF-a-induced secretion of interleukin-8 from Caco-2 cells. J Agric Food Chem. 2008; 56(10): $3863-3868$. [CrossRef]

[53] Segheto L, Santos BCS, Werneck AFL, Vilela FMP, Vieira de Sousa O, Rodarte MP. Antioxidant extracts of coffee leaves and its active ingredient 5-caffeoylquinic acid reduce chemically-induced inflammation in mice. Ind Crops Prod. 2018; 126: 48-57. [CrossRef]

[54] Ginwala R, Bhavsar R, Chigbu DGI, Jain P, Khan ZK. Potential role of flavonoids in treating chronic inflammatory diseases with a special focus on the anti-inflammatory activity of apigenin. Antioxidants. 2019; 8(2): 35. [CrossRef]

[55] Ali F, Rahul, Naz F, Jyoti S, Siddique YS. Health functionality of apigenin: A review. Int J Food Prop. 2017; 20(6): 1197-1238. [CrossRef]

[56] Chiang LC, Ng LT, Lin IC, Kuo PL, Lin CC. Anti-proliferative effect of apigenin and its apoptoticinduction in human Hep G2 cells. Cancer Lett. 2006; 237(2): 207-214. [CrossRef]

[57] Braganhol E, Zamin LL, Canedo AD, Horn F, Tamajusuku ASK, Wink MR, Salbego C, Battastini AMO. Antiproliferative effect of quercetin in the human U138MG glioma cell line. Anticancer Drugs. 2006; 17(6): 663-671. [CrossRef]

[58] Kleemann R, Verschuren L, Morrison M, Zadelaar S, Erk MJ, Wielinga PY, Kooistra T. Anti-inflammatory, antiproliferative and anti-atherosclerotic effects of quercetin in human in vitro and in situ models. Atherosclerosis. 2011; 218(1): 44-52. [CrossRef] 
[59] Zou Y, Chang SK, Gu Y, Qian SY. Antioxidant activity and phenolic compositions of lentil (Lens culinaris var. morton) extract and its fractions. J Agric Food Chem. 2011; 59(6): 2268-2276. [CrossRef]

[60] Phosrithong N, Nuchtavorn N. Antioxidant and anti-inflammatory activites of Clerodendrum leaf extracts collected in Thailand. Eur J Integr Med. 2016; 8(3): 281-285. [CrossRef]

[61] Yıldırım A, Şen A, Doğan A, Bitis L . Antioxidant and anti-inflammatory activity of capitula, leaf and stem extracts of Tanacetum cilicicum (Boiss.) Grierson. Int J Second Metab. 2019; 6(2): 211-222. [CrossRef]

[62] Gao X, Ohlander M, Jeppsson N, Björk L, Trajkovski V. Changes in antioxidant effects and their relationship to phytonutrients in fruits of Sea Buckthorn (Hippophae rhamnoides L.) during maturation. J Agric Food Chem. 2000; 48(5): 1485-1490. [CrossRef]

[63] Zhang R, Zeng Q, Deng Y, Zhang M, Wei Z, Zhang Y, Tang X. Phenolic profiles and antioxidant activity of litchipulp of different cultivars cultivated in Southern China. Food Chem. 2013; 136(3-4): 1169-1176. [CrossRef]

[64] Csapi B, Hajdú Z, Zupkó I, Berényi A, Forgo P, Szabó P, Hohmann J. Bioactivity-guided isolation of antiproliferative compounds from Centaurea arenaria. Phytother Res. 2010; 24(11): 1664-1669. [CrossRef]

[65] Zengin G, Zheleva-Dimitrova D, Gevrenova R, Nedialkov P, Mocan A, Ćirić A, Glamočlija J, Soković M, Aktumsek A, Mahomoodallye MF. Identification of phenolic components via LC-MS analysis and biological activities of two Centaurea species: C. drabifolia subsp. drabifolia and C. lycopifolia. J Pharm Biomed. 2018; 149: 436-441. [CrossRef]

[66] Bakr RO, Mohamed SAEH, Ayoub N. Phenolic profile of Centaurea aegyptiaca L. growing in Egypt and its cytotoxic and antiviral activities. Afr J Tradit Complement Altern Med. 2016; 13(6): 135-143. [CrossRef]

This is an open access article which is publicly available on our journal's website under Institutional Repository at http://dspace.marmara.edu.tr. 